\title{
AGENDA SETTING E EDUCAÇÃO
}

\section{Os meios de comunicação determinam os temas das conversas dos cidadãos dos diferentes níveis sociais, conformando a realidade aos fatos veiculados pelas mídias}

O uso de produtos da mídia como material pedagógico em sala de aula é tema da moda nos círculos da educação e da comunicação. Embora essa experiência e os estudos sobre ela tenham origem na Europa, países sul-americanos como Brasil e Argentina já apresentam relativo desenvolvimento na área. Os jornais O Estado de S.Paulo, Folha de S.Paulo, A Tribuna (Santos), O Globo, El Clarín, La Voz del Interior (Córdoba) já possuem projetos de integração com instituições de ensino básico. Este uso escolar de informação veiculada pelos meios de comunicação tem objetivos mais ou menos definidos por comunicadores e sobretudo educadores. No entanto, para que estes objetivos sejam atingidos, algumas precauções, relacionadas à preparação dos docentes, devem ser tomadas.

\section{OBJETIVOS}

Na elaboração e gestão de um processo pedagógico as estratégias são definidas em função de objetivos pré-estabelecidos. $\mathrm{O}$ uso de material informativo de jornal, revista ou mesmo televisão visa trazer para a sala de aula um conjunto de temas que per- tencem à agenda pública de discussão social, atribuindo, assim, um fim pedagógico ao efeito agenda setting.

\section{O que é agenda setting?}

O leitor menos afeito ao jargão das teorias de comunicação de massa deve estar esperando algum esclarecimento sobre o termo agenda setting (fixação de agenda). É a hipótese segundo a qual a agenda temática dos meios de comunicação impõe os temas de discussão social. Em outras palavras: as pessoas, nas suas comunicações interpessoais, discutem prioritariamente sobre os temas abordados pelos meios de comunicação. ${ }^{1}$

Essa hipótese é intuitiva e de fácil compreensão. Os exemplos poderiam se multiplicar ao infinito. Caso da modelo Lílian Ramos, ao lado do então presidente Itamar Franco, durante o carnaval de 1994; ou

\section{O AUTOR}

Clóvis de Barros Filho

Pesquisador do Departamento de Comunicação Pública da Universidade de Navarra, bolsista do $\mathrm{CNPq}$ e professor do Curso Intensivo de Jornalismo Aplicado de $\mathbf{O}$ Estado de S. Paulo.

1. Sobre o conceito de agenda setting ler: McCOMS, Maxwell e SHAW, Donald, The agenda setting function of mass media. (A função da agenda setting na mídia). Public Opinion Quartely, n.36, 1972, p. 176-178. WOLF, Mauro. $O$ estudo dos efeitos a longo prazo - a hipótese do agenda setting. In: Teorias da comunicação. 2. ed. Lisboa: Presença, 1992, p.123-156. 
o de traços de cocaína encontrados no exame antidopping do goleiro Zetti durante as eliminatórias da Copa do Mundo na Bolívia integraram a agenda pública e, dessa forma, foram objeto de discussão social. Tanto a falta de indumentária íntima da modelo em situação quase protocolar, como as possíveis conseqüências estimulantes de um consumo de folhas de chá de cocaína do goleiro não são temas de discussão ordinária durante um café da manhã em família. Passaram a sê-lo em função do efeito agenda setting.

A rigor, essa imposição temática pode ser vista como uma forma de manipulação. Ao selecionar alguns temas que comporão o produto informativo, os meios de comunicação determinam o que aconteceu, dão a alguns fatos existência social, mas condenam às trevas, ao desconhecimento social, um número infinitamente maior de temas também mediatizáveis.

Ora, esta construção da realidade social operada pelos meios, por intermédio de uma seleção e hierarquização arbitrária de eventos, produz efeitos: promove discussões sociais encapsuladas pela barreira do desconhecimento dos temas jogados no lixo das reuniões de pauta dos jornais ${ }^{2}$, ou dos que nem chegaram a ela.

No entanto, essa imposição temática também pode ser vista de maneira menos apocalíptica e mais integrada. A realidade social é crescentemente complexa. O mundo social se especializa em velocidade progressiva. A vida em sociedade só se viabili- za em função de mecanismos redutores dessa complexidade ${ }^{3}$. Os meios de comunicação, ao darem forma àquilo que está disperso e latente, oferecem às pessoas um mínimo denominador comum de temas sobre os quais conversar.

A leitura de uma manchete numa banca de jornal dá ao receptor a segurança de ter o que dizer, de poder interagir, de pertencer a um sistema comum de consumo ${ }^{4}$. Essa canalização permite ao professor de física nuclear conversar com um conhecido ator de teatro sobre as novas peripécias de Romário, o exagero de viagens do presidente da República ou a violência do furação em Miami.

A pergunta que surge no espírito do leitor é uma só: de que forma esse menu temático de discussão pode interagir com o processo pedagógico?

\section{Agenda setting na sala de aula}

Mídia e escola são dois espaços públicos, instâncias de socialização e de aprendizado social. Ambas exigem ritualização, produzindo efeitos a curto, médio e longo prazos. Fornecem informação imediata e de uso imediato e constroem um universo simbólico estruturado por referenciais de apreciação da realidade. Ambas impõem regras de comportamento social e regras de classificação do mundo social.

Tanto uma quanto a outra têm papel decisivo na constituição do habitus $^{5}$, entendido como conjunto de esquemas de apreciação e de valoração da realidade social interiorizadas durante toda a trajetória so-

2. São reuniōes em que os responsáveis pela redação do jornal, revista, telejornal ou radiojornal, reúnem-se com os jornalistas para realizar a triagem do que será reportado e noticiado em uma edição, por aqueles veículos de comunicação.

3. Sobre os meios como redutores da complexidade social ler NAVAS. Alejandro, La función integradora de los medios de comunicación en el pensamiento de Niklas Luhmann, in: LÓPEZ-Escobar \& ORIHUELA (eds.), La responsabilidad pública del periodista. Pamplona: Universidad de Navarra, 1988.

4. Sobre este conceito ler: BAUDRILLARD, Jean. Sociedade de consumo. Lisboa: Edições 70, 1976.

5. Sobre o conceito de habitus ler BOURDIEU, Pierre. Le sens pratique.(O senso prático) Paris: Minuit, 1980 . p. 87-111. 
cial do indivíduo. Essa interiorização é condicionadora do comportamento sem ser fruto de uma orquestração estratégica, de escolhas conscientes envolvendo um cálculo custo/benefício.

As regras de comportamento socialmente construídas são tanto mais determinantes quanto menos são percebidas enquanto regras. As teorias de aculturação como efeito da recepção ritualizada dos meios de comunicação e como conseqüência do processo pedagógico escolar apresentam semelhanças incontestáveis.

A intersecção da recepção mediática com o processo pedagógico escolar dentro da perspectiva da comunicação nos faz pensar antes de tudo na agenda temática a ser definida. Embora o conteúdo do material pedagógico seja quase um pretexto para a construção e desenvolvimento das estruturas de conhecimento por parte do aluno, é inegável que a motivação, sempre associada ao interesse pelo tema, e decorrente da gratificação psicológica obtida, é ponto nevrálgico em toda a evolução do aprendizado.

$\mathrm{O}$ processo pedagógico na escola é composto pela aula, cujas oportunidades de expressão do aluno são dirigidas pelo professor, e por atividades nas quais o aluno se relaciona com seus colegas sem a intervenção direta do educador. Costuma-se falar, na pedagogia moderna, em espaços de relação espontânea, para se referir ao recreio, entrada e saída de aula etc. Essa espontaneidade, no entanto, estará sempre condicionada pela escola enquanto instância de socialização promotora das relações que nela se desenvolvem. Se o local do encontro fosse outro, clube, rua, festa, casa de um amigo, os comportamentos e expectativas de comportamento seriam distintos.
No espaço escolar o aluno relacionase com seus colegas em função de três tipos de agenda temática. A agenda pessoal de cada um, quase sempre comentada entre os colegas de relação mais estreita. Aqui cada qual expõe fatos, opiniões que digam respeito à experiência vivida. Um segundo tipo de temas de discussão nas relações intra-escola diz respeito à agenda do grupo instituído que pode ser a classe como um todo ou grupos ocasionais impostos ou não pelo educador. Os temas desse segundo tipo de agenda são os que mais se aproximam dos programas desenvolvidos pelos professores, seu próprio discurso, livros de referência, questões de prova, horário de aulas, lições de casa etc.

O terceiro tipo de temas discutidos pelos alunos pertence à chamada agenda pública da sociedade. Aqui, questões de conhecimento público, ou seja, questões que pertencem a um menu temático compartilhado por toda a sociedade, são objeto de intervenção dos alunos. Compõem este tipo de agenda temática temas políticos como corrupção, eleições, candidatos; temas econômicos como inflação, moeda, salário; temas esportivos como resultados de jogos de futebol, atuação de jogadores, contratações etc.

Não raro, o que acaba discriminando essas três agendas não é o conteúdo do tema discutido e sim o enfoque dado.

A violência, por exemplo, é objeto de estudo que pode estar presente nas três agendas temáticas. Um aluno que conta a experiência de um assalto em sua casa, uma questão de prova que envolva o tema, ou a própria discussão do fenômeno da violência nos grandes centros urbanos são maneiras distintas de trabalhar a mesma questão. 
Hoje há uma tendência em incentivar em sala de aula discussões que envolvam esse terceiro tipo de agenda temática. Imediatamente o produto informativo oferecido pelos meios de comunicação surge como fonte privilegiada. Visa-se promover um agendamento de temas especifícos, através, por exemplo, da leitura de jornais. Para isso procura-se oferecer ao aluno um conjunto de referenciais que permitam associações com novas informações recebidas e, com isso, despertar um interesse sobre esses temas.

Se os meios de comunicação impõem os temas de discussão social (agenda setting), procura-se utilizar este efeito de forma direcionada e combinada ao processo pedagógico em sala de aula. Para comunicadores e pedagogos, esse processo deve permitir ao aluno, através de uma recepção dirigida, desenvolver um espírito crítico em relação às mensagens veiculadas, incentivar o contraste com outros referenciais e promover a discussão de opiniões e interpretações. Como observou o diretor e dono do jornal La Voz del Interior de Córdoba (Argentina): "é preciso que os alunos saibam o que acontece, conheçam a realidade; a realidade trazida pelo jornal interessa mais os alunos que a ficção dos livros"6.

A essa postura, aparentemente atraente, postulamos algumas advertências relacionadas com a necessária preparação dos docentes para que, no uso deste tipo de material, não incorram em equívocos do senso comum.

\section{PRECAUÇÕES}

A obsessão com o material pedagógico pode levar a uma negligência: a prepara- ção cuidadosa dos docentes. O professor de segundo grau, via de regra sem competência específica para aplicar material de imprensa e falar sobre mídia em geral, acabará, por intermédio de um discurso do senso comum $^{7}$ legitimado pela instituição escolar, impondo a sua representação do que é o jornal e de suas funções. Apresentaremos três idéias do senso comum que podem atrapalhar o processo pedagógico: a associação do jornal à realidade, o uso do jornal em sala de aula equiparado ao uso do leitor comum e o produto informativo como socializador do conhecimento.

\section{O espelho da realidade}

O chamado "espírito crítico", que nasce da capacidade de contrastar, diferenciar e associar novas mensagens a referenciais previamente estruturados, depende, no caso da recepção de informações mediatizadas, de noções sobre o que é o produto informativo. Não é incomum professores de primeiro e segundo graus recomendarem aos alunos a leitura de jornais para que conheçam a realidade, "saibam o que está acontecendo lá fora", "estejam ligados no que rola no mundo". Essa sugestão, sem algumas advertências paralelas, produz efeitos negativos.

Associar a informação mediatizada à realidade faz crer na sua transparência, ou seja, na correspodência absoluta entre o texto e o fato a ser descrito. Observe-se que esta é a representação do jornal ideal imposta por grande parte do material publicitário sobre os meios. Diante de "Aconteceu Virou Manchete", é legítimo crer que se não virou manchete não aconteceu. No mesmo sentido "O que pinta de novo pinta na tela da

6. Entrevista realizada na sede do jornal em Córdoba, em 8/8/95.

7. Sobre a ideologia do senso comum, sua produção e reprodução socialmente interessada e seus efeitos ler: BOURDIEU, Pierre, Questões de sociologia. Rio de Janeiro: Marco Zero, 1983. 
Globo", "Mostrando a vida como ela é", ou mesmo "Plugado no mundo". Esta ilusão de mostrar a vida como ela é tem como principal ponto de apoio a aparência de objetividade do texto e da imagem jornalísticos.

É preciso que o aluno saiba que o jornal é fruto de um conjunto de escolhas e seleções arbitrárias. $O$ texto informativo, como qualquer enunciado, é um processo específico de individualização da linguagem enquanto código de significação. Quando um jornalista redige uma matéria, materializa um processo ininterrupto de escolhas, de eliminações que acabam constituindo uma mensagem entre uma infinidade de possibilidades preteridas. Além das escolhas estritamente formais de sintaxe, de léxico, opera-se uma seleção temática.

Quando se fala em imposição temática, em escolha arbitrária, imediatamente se fala em manipulação. A manipulação, no entanto, não está na seleção, que é inevitável em função das limitações de tempo e espaço do produto. Está sim no golpe de violência simbólica que procura impor a parte pelo todo, fazer crer que o universo de temas elegidos como mediáticos pela ,reunião de pauta sejam a própria realidade fenomênica; ou seja, seria insólito imaginar um slogan do tipo: "Aconteceu (passou pela reunião de pauta, a reportagem foi possível, o editor gostou, havia espaço para a publicação, o tema não envelheceu de uma semana para outra), Virou Manchete".

Trata-se de um tema de ética informativa. Cabe uma advertência aos alunos. A imposição de um produto codificado e, portanto, em certa medida ficcional, como sendo a realidade, inacessível para o leitor, é a própria essência do produto informativo mediatizado. A ausência aparente do autorjornalista, provocada por uma padronização estilística crescente (manuais de estilo) significa ausência de codificador, de código, de intermediário e, conseqüentemente de seleção. A imagem informativa, ao incidir seu foco e suas luzes sobre este ou aquele ângulo, condenam à inexistência social qualquer outro, potencialmente mediatizável.

\section{Limites da agenda temática dos alunos}

O professor desavisado que aplica o jornal como material pedagógico pode prestar um desserviço. O uso do jornal em sala de aula deve ter objetivos distintos do seu uso pelo leitor comum. Se o objetivo final do processo pedagógico for transmitir conteúdo, opera-se uma segunda canalização temática, reconstrutora da realidade social e legitimizada pela instituição escolar.

O processo pedagógico deve esclarecer e advertir sobre os eventuais efeitos nefastos que a recepção do produto informativo pode produzir, e não reforçá-los.

O estudo do material informativo deve ser epistemológico, de método (ou seja, neste caso, relativo ao conhecimento dos processos de comunicação) e não temático. Se o objetivo é a discussão e o desenvolvimento do "espírito crítico", é inútil transformar o aluno num deglutidor hipocondríaco de pílulas informativas.

De acordo com algumas pesquisas, o segundo e terceiro tipos de agenda, isto é, os temas relacionados com as atividades propriamente pedagógicas e os temas de agenda pública, têm uma limitação quantitativa. Tanto em universos sociais circunscritos como na sociedade como um todo, o número de temas de discussão não ultrapassa um teto que varia em função das características cul- 
turais do grupo. Desta forma, para que novos temas se incorporem à agenda de discussão é necessário que outros, paralelamente, sejam esquecidos. Isso significa que a introdução dirigida de um tema no processo pedagógico corresponde ao desagendamento de algum outro tema. $\mathrm{O}$ grupo regula naturalmente $\mathrm{o}$ congestionamento temático. Daí a inutilidade da saturação na transmissão temática.

$\mathrm{O}$ uso que o leitor comum faz da informação consumida é quase sempre imediato. É tão perecível quanto a própria notícia. Saber o valor do dólar marcado no jornal tem a validade de algumas horas.

A velocidade de agendamento e desagendamento temático assume um ritmo tão alucinante quanto o número crescente de notícias veiculadas. Neste sentido, é conhecido o comentário de que há mais informações num só número do New York Times do que poderia receber um cidadão inglês durante toda sua vida no século XVII.

Este uso não deve ser confundido com o uso pedagógico da recepção informativa trabalhada em sala de aula. São, a rigor, incompatíveis e incomparáveis.

A recepção mediática normal leva a uma crescente diferenciação no processo de apreensão de conhecimento (Knowledge gap) entre consumidores assíduos e, portanto, melhor preparados para um certo tipo de absorção informativa e consumidores eventuais. No processo pedagógico, cabe ao docente reduzir ao máximo essas discrepâncias.

\section{Informação socializadora do conhecimento}

Não são raras as análises de especialistas em comunicação de massa que atribuem à informação mediatizada um efeito sociali- zador do conhecimento. Sobretudo após a popularização definitiva da televisão, e seu consumo indiscriminado em todas as classes sociais, essa prerrogativa de redução das desigualdades cognitivas na sociedade vem sendo apregoada com ares de conclusão científica inquestionável.

As pesquisas empíricas, no entanto, demonstram o contrário. Quanto mais intensos o bombardeio e o consumo informativo, mais acentuadas as diferenças de apreensão do conhecimento entre bem-preparados e mal-preparados.

Não há ponto de tangência mais visível entre a educação e as teorias de comunicação de massa do que este efeito social das discrepâncias de apreensão de conhecimentos. Não se trata de um efeito exclusivo do consumo informativo. A ação conjunta de todas as instâncias pedagógicas da sociedade como família, escola, igreja, mídia acabam produzindo uma sociedade em vários níveis, coincidentes, em grande parte, com a estratificação econômica.

Aqui, o uso da informação mediatizada não se distingue dos demais materiais pedagógicos. Não é porque os temas da agenda pública são discutidos em sociedade, e portanto provavelmente já conhecidos dos alunos, que a competência específica para discutir sobre eles será mais homogênea. Ao contrário. Há uma tendência por parte do aluno, quando indagado sobre temas que escapam à sua agenda privada, de buscar um discurso de compromisso entre a opinião dominante do público que o ouve (no nosso caso a classe), e as intervenções sobre o tema já ouvidas, sobretudo no seio familiar. As diferentes capacidades de percepção do material oferecido, observado entre os alunos de uma mesma sala de aula, será, em parte, reveladora de outras diferenças pre- 
sentes nas dimensões de socialização, sobretudo na família, onde o aluno ouviu comentários sobre o tema, ou não.

Para o docente as dificuldades se multiplicam. Um dos principais impasses é o de buscar a redução de tais discrepâncias sem frear os mais aptos. O que deve estar claro é que o mero uso de jornais em nada contribuirá para isso.

Estas advertências não devem significar, de forma nenhuma, um desencorajamento. Ao contrário. São um convite ao do- cente que pretende efetivamente enriquecer e inovar sua estratégia pedagógica. Elas se fazem tanto mais necessárias quanto mais aguda é a evolução do uso das novas tecnologias de comunicação coletiva. Quanto mais sofisticado o meio (a mídia) mais obscuro e aparentemente inexistente é o papel do codificador, mais aparente e ilusório será o vínculo da notícia com a realidade e mais acentuados serão os intervalos de percepção da mensagem veiculada nos distintos universos sociais. 